\title{
Field Management Effects on Damping-Off and Early Season Vigor of Crops in a Transitional Organic Cropping System
}

\author{
Fulya Baysal, Maria-Soledad Benitez, Matthew D. Kleinhenz, Sally A. Miller, and Brian B. McSpadden Gardener
}

First, second, fourth, and fifth authors: Department of Plant Pathology, and third author: Department of Horticulture and Crop Sciences, Ohio Agricultural Research and Development Center, The Ohio State University, 1680 Madison Ave, Wooster 44691. Accepted for publication 14 January 2008.

\begin{abstract}
Baysal, F., Benitez, M.-S., Kleinhenz, M., Miller, S. A., and McSpadden Gardener, B. B. 2008. Field management effects on damping-off and early season vigor of crops in a transitional organic cropping system. Phytopathology 98:562-570.

Transitioning farmland to certified organic vegetable production can take many paths, each varying in their costs and benefits. Here, the effects of four organic transition strategies (i.e., tilled fallowing, mixed-species hay, low-intensity vegetables, and intensive vegetable production under high tunnels), each with and without annual compost applications for 3 years prior to assessment, were characterized. Although transition cropping strategies differed in soil chemistry $(P<0.05)$, the magnitude of the changes typically were marginal and pairwise comparisons were rarely significant. In contrast, the compost amendment had a much greater impact on soil chemistry regardless of cropping strategy. For example, percent $\mathrm{C}$ and total $\mathrm{P}$ increased by 2 - to 5 -fold and $\mathrm{K}$ increased

from 2 to $30 \%$ in soils from the mixed-hay transition. In the field, damping-off of both crops was also significantly lower in plots previously cropped to hay $(P<0.05)$. Although not always significant $(P<0.05)$, this pattern of suppression was observed in all four of the soybean experiments and three of the four tomato experiments independent of compost application. The compost amendments alone did not consistently suppress damping-off. However, plant height, fresh weight, and leaf area index of the surviving seedlings of both crops were greater in the compost-amended soils regardless of the transitional cropping treatment used $(P<0.05$ for most comparisons). These data indicate that mixed-hay cropping during the transition periods can enhance soil suppressiveness to damping-off. In addition, although compost amendments applied during transition can improve crop vigor by significantly enhancing soil fertility, their effects on soilborne diseases are not yet predictable when transitioning to certified organic production.
\end{abstract} from 6- to 12-fold. Under controlled conditions, damping-off of both edamame soybean (cv. Sayamusume) and tomato (cv. Tiny Tim) was reduced
Additional keywords: soilborne disease suppression, transition treatment.
Small and midsized family farmers are under intense pressure to remain profitable, particularly in peri-urban areas. Increased sprawl, shrinking agricultural infrastructures, low commodity prices, and less tolerance for some conventional farming practices constrain agricultural systems near urban centers. The higher market value of organic produce and their proximity to large urban centers encourage some farmers to transition to organic vegetable production. The National Organic Standards Act (NOS) allows for certification only after 3 years have passed since the last use of a restricted substance. Growers approach the mandated 3-year transition period in different ways. Their options are coarsely defined based on time constraints, markets, and land, labor, equipment, and other costs. Published studies of transition experiments have shown that there is often a period of lowered yields similar to conventional production $(21,22)$. This "transition effect" has been attributed, in part, to changes in the soil biological, chemical, and physical properties governing nutrient cycling, plant growth, and development $(40,28)$. In the second and fifth years after conversion, Doran et al. (8) showed that microbial populations and activities in surface soil of organic and conventional treatment systems were influenced primarily by type of crop grown and, to a lesser extent, by soil physical properties. Sahs and Lesoing (30) reported significantly higher soil organic matter and total $\mathrm{N}$ in the organic than the conventional treatment 5 years after establishment of the experiment. These studies indicate that management

Corresponding author: B. B. McSpadden Gardener; E-mail address: bbmg+@ osu.edu

doi:10.1094/PHYTO-98-5-0562

(c) 2008 The American Phytopathological Society practices applied during the transition period can have a substantial effect on the health and productivity of subsequent organic crops.

Management of soil organic matter to enhance soil quality and supply nutrients is a key determinant of successful organic farming. This involves balancing two ecological processes: mineralization of carbon and nitrogen in soil organic matter for short-term crop uptake, and sequestering carbon and nitrogen in soil organic matter pools for long-term maintenance of soil and environmental quality $(6,18)$. Tillage, rotation, mulches, cover crops, and organic amendments are all known to influence soil organic matter composition and the structure and activity of microbial communities $(11,19,20,27,34,37)$. Thus, nutrient transformations and soilborne disease suppression catalyzed by microbes are closely linked to turnover of biologically active soil organic matter $(14,26)$. Composted animal manures have long been known to provide benefits to soil systems by improving soil structure and nutrient availability and are part of the foundation of organic fertility management (7). Another benefit of composts can be the suppression of soilborne plant diseases. Compost products are particularly effective in the suppression of Pythium ultimum and Rhizoctonia solani. These fungi represent different types of plant pathogens and may be affected differently by compost amendments (14). The vegetable production system may influence the efficacy of suppressive composts. Organic production systems use plant and animal manures to provide regular inputs of organic matter. In some cases, organic systems have been shown to result in diseasesuppressive soils, based on the research measures of microbial activity and disease incidence (38).

The 3-year transition from conventional to organic crop production is considered to be potentially risky to farmers, because 
conventional inputs (synthetic fertilizers, pesticides, and genetically modified crops) are withdrawn but the benefits of an organic production system are not yet realized. A large number of transition strategies may be undertaken; however, there is little information available on the effects of these approaches on soil microbiology and crop health. In this research, we investigated the effects of four primary transition treatments (i.e., tilled fallowing, mixed-species hay, low-intensity field vegetables, and intensive vegetable production under high tunnels) and two secondary treatments related to fertility management during transition (i.e., plus and minus compost). In order to determine the generality of the observed effects, soilborne disease suppressiveness was assayed on two different crops grown under a variety of different conditions. Thus, the goal of this research was to characterize the impact of various transition strategies on soil chemical characteristics and soilborne disease suppressiveness. Work describing the effects of these same transition strategies on soil and rhizosphere bacterial populations and their potential contributions to the patterns of damping-off suppression described in this article has been published recently (2).

\section{MATERIALS AND METHODS}

Field plot design and management. A replicated factorial transition experiment was established at the Ohio Agricultural Research and Development Center (OARDC) in Wooster, OH. Soil at this site is a moderately well-drained Wooster silt loam, initially with approximately $2.2 \%$ organic matter. The four primary transition treatments and two secondary treatments were arranged as split plots, with main plots replicated four times in a randomized complete block design. Whole-field plots were 18.3 by $17.1 \mathrm{~m}$ long. The four-by-two factorial treatments were managed as a 3-year transition and, in the fourth year (2006), all subplots were cropped to tomato. In October 2006, the land was certified by The Ohio Ecological Food and Farm Association (OEFFA) according to the NOS rules. Organic Materials Review Institute (OMRI)-approved insect and disease management inputs were used as needed following weekly scouting.

The four primary treatments were tilled fallowing (TF), single planting of mixed-species perennial hay, low-intensity open field vegetables, and intensive vegetable production under high tunnels. In the tilled fallowing plots, weed seedlings were removed repeatedly throughout the year and a cover crop (rye or wheat) was planted in the fall every year to help prevent erosion and was incorporated into the soil every spring to add organic matter back into the soil. The mixed-hay $(\mathrm{H})$ treatment consisted of a combination of eight hay species in equal proportions, including: festulolium (or rye fescue) undersown with alfalfa, red and white clover, timothy, chicory, orchardgrass and plantain. In the mixedspecies hay plots, two or three cuttings were taken each year by mowing off the foliage, allowing it to dry on the ground, and removing it from the plots. Foliage was incorporated into the soil of the hay plots only in spring of 2006. The low-intensity open field vegetables (FV) treatment consisted of potato-mixed vegetables (lettuce, spinach, swiss chard, radish, and beet) in 2003, butternut squash-wheat in 2004, and green bean-lettuce-wheat in 2005. The intensive vegetable production under high tunnels (HT) treatment consisted of potato-mixed vegetables (lettuce, spinach, swiss chard, radish, and beet) in 2003, mixed vegetables-zucchini squash-mixed vegetables in 2004, and mixed vegetables-green bean-mixed vegetables in 2005. High tunnels were constructed as plastic enclosed structures $(6.4$ by $14.6 \mathrm{~m})$ with partial control over environmental variables for extending the vegetable crop growing period.

The secondary treatments were related to fertility management during transition. Half of each main plot received no organic amendment or the annual addition of composted $60 \%$ separated dairy solids, $30 \%$ sawdust bedded manure, and $10 \%$ straw bedded manure (18.6 t/ha dry weight). Compost was incorporated in three summer additions in tilled fallowing, spread over the surface after hay harvests in mixed-species hay, and incorporated prior to the main summer crop in low-intensity vegetables and intensive vegetable production under high tunnels. The same quantity of compost was incorporated prior to planting tomato in the fourth year for the four primary treatments.

The irrigation system for the project was drip irrigation. The drip tape used during all 4 years was 510-12-450 TSX with water being released at a rate of 1.70 liter/min per $30.48 \mathrm{~m}$ of tape. Drip irrigation was in place in the high tunnels and open-field vegetables plots each year from 1 April to 1 November; from 1 November to 1 April, irrigation was done in the high tunnels by hand with watering cans. Irrigation was done as needed for the first 3 years based on visual appearance of the soil and the weather. In 2006 , plots were on a regular irrigation schedule of 3 days/week for 4 to $6 \mathrm{~h}$ per day, unless it had rained.

Soil sampling. Soils were sampled from the field on 12 April 2005 for the first and second bioassays, and a subsequent independent sampling occurred on 2 November 2005 for the third bioassay. Four soil samples (900 $\mathrm{cm}^{2}$ and $10 \mathrm{~cm}$ deep) were removed randomly from each subplot, mixed in situ with a spade, and placed in a plastic bucket. The soils were stored covered, at ambient temperature, in a greenhouse for up to 4 months prior to use in the greenhouse and growth chamber assays described below.

Soil chemistry analysis. Soil from each sampling unit was tested independently at the Service Testing and Research (STAR) laboratory (OARDC, Wooster, OH) in spring and fall 2005. Soil samples were air dried at a temperature of 25 to $35^{\circ} \mathrm{C}$, then ground and passed through a $2-\mathrm{mm}$ sieve. Total nitrogen and carbon were analyzed using the Dumas method following the AOAC Official Methods of Analysis (1). pH was analyzed in a 1:1 ( $\mathrm{vol} / \mathrm{vol}$ ) water extract using a $\mathrm{pH}$ meter following the Watson and Brown methods (41). The extractable ions (P, K, Ca, Mg, S, Al, $\mathrm{Cu}, \mathrm{Fe}, \mathrm{Mn}$, and $\mathrm{Zn}$ ) were analyzed by ICP Spectrometry with Mehlich 3 soil test extractant in a 1:10 (vol/vol) Mehlich 3 extracting solution (24).

Greenhouse and growth chamber bioassays for soilborne disease suppressiveness. Three separate experiments were conducted using two different crops (i.e., tomato and soybean) under differing levels of pathogen pressure. For each bioassay, the experimental design was a randomized complete block with three replicates of eight different soil transition treatments. Approximately $450 \mathrm{~cm}^{3}$ of soil per replicate from each transition plot was placed into plastic pots and seeded $0.5 \mathrm{~cm}$ deep with 20 tomato cv. Tiny Tim (Stokes Seeds, Buffalo, NY) seeds or $1 \mathrm{~cm}$ deep with 6 edamame soybean cv. Sayamusume (Territorial Seed Company, Cottage Grove, OR) seeds. For experiment 1, soil sampled on 12 April was used with no supplemental pathogen inoculum. Subsequently, experiments 2 and 3 were conducted with pathogen-amended soils using April- and November-sampled soils, respectively. For tomato, pots were amended with $P$. aphanidermatum isolate 349 inoculum. Soil was added to 10-by-10-by9-cm containers to a depth of $2.5 \mathrm{~cm}, P$. aphanidermatum was grown in 9-cm-diameter petri dishes on water agar medium at $23^{\circ} \mathrm{C}$ for 7 to 10 days; then, $106-\mathrm{mm}$ plugs removed from the growing edge of the colony were placed on the soil surface and misted with 10 of $\mathrm{ml}$ sterile distilled water. The containers then were filled with the remaining soil $\left(450 \mathrm{~cm}^{3}\right.$ total). For soybean, pots were amended with Phytophthora sojae isolate 25 and $P y$ thium ultimum inoculum obtained from A. Dorrance, Ohio State University. Phytophthora sojae and Pythium ultimum were grown on $1 / 30 \times$ trypticase soy agar (TSA) medium at $23^{\circ} \mathrm{C}$ for 7 and 3 days, respectively; then, five 6-mm plugs removed from the growing edge of each colony were placed on the soil surface, misted with $10 \mathrm{ml}$ of sterile distilled water, and filled with the remaining soil. Containers were placed in the greenhouse (experiment 1) or growth chamber (experiments 2 and 3). Day and night 
temperatures of 27 and $21 \pm 2{ }^{\circ} \mathrm{C}$, respectively, were maintained in the greenhouse, and the growth chamber was maintained at 20 and $15^{\circ} \mathrm{C}$, day and night, respectively, with a 14-h day length and $55 \%$ relative humidity. Water was applied to the top of each container daily at a rate of $65 \mathrm{ml} /$ day/container through a siphon delivery system (25). Experiments were terminated 21 and 14 days after seeding for tomato and soybean, respectively.

Field bioassays. Field bioassays were conducted in 2006, the year of organic certification, when all plots were planted to tomato cvs. Mountain Spring (Siegers Seed Company, Holland, MI) and Florida 47 (Siegers Seed Company). Due to a lack of space in the high tunnels, these field bioassays were conducted only for the open-field sites that had undergone tilled fallowing, mixed-hay cropping, or open-field vegetable cropping, with and without compost amendment during the transition period from 2003 through 2005. As noted above, the main plots were arranged as split plots with main plots replicated four times in a randomized complete block design. In each plot, 24 tomato cv. Tiny Tim (Stokes Seeds) and 16 edamame soybean cv. Sayamusume (Territorial Seed Company) seeds were sown directly in two 45-by$45-\mathrm{cm}$ areas per subplot within the field. As in the experiments described above, seedlings were sampled after 21 and 14 days after sowing for tomato and soybean, respectively.

Measurements of crop health. Stand and vigor data were recorded for tomato and soybean in the greenhouse, growth chamber, and field experiments. Stand counts per container or field site were used as a measure of damping-off. Emergence was recorded at 15 and 18 days after planting and final stand 3 days later for tomato, and at 8 and 11 days after planting and final stand 3 days later for soybean. The percentage of damping-off was calculated

TABLE 1. Analysis of variance for soil $\mathrm{pH}, \mathrm{N}, \mathrm{C}$, and extractable nutrient status, fall $2005^{\mathrm{x}}$

\begin{tabular}{|c|c|c|c|}
\hline Source & $\begin{array}{l}\text { Organic } \\
\text { transition }^{\mathrm{y}}\end{array}$ & $\begin{array}{c}\text { Compost } \\
\text { amendment }^{z}\end{array}$ & $\begin{array}{l}\text { Organic transition } \\
\times \text { compost }\end{array}$ \\
\hline \multicolumn{4}{|l|}{$\mathrm{pH}$} \\
\hline Mean square & 1.3 & 0.6 & 0.1 \\
\hline$F$ value & $21.9^{*}$ & $13.4^{*}$ & $6.7 *$ \\
\hline \multicolumn{4}{|l|}{$\mathrm{N} \%$} \\
\hline Mean square & 0 & 0.3 & 0 \\
\hline$F$ value & $13.8^{*}$ & $432.0^{*}$ & $8.8^{*}$ \\
\hline \multicolumn{4}{|l|}{$\mathrm{C} \%$} \\
\hline Mean square & 3.2 & 43.7 & 2 \\
\hline$F$ value & $16.2^{*}$ & $447.5^{*}$ & $10.8^{*}$ \\
\hline \multicolumn{4}{|l|}{$\mathrm{P}$} \\
\hline Mean square & 8,998 & 123,330 & 6,427 \\
\hline$F$ value & $14.3^{*}$ & $403.5^{*}$ & $8.6^{*}$ \\
\hline \multicolumn{4}{|l|}{$\mathrm{K}$} \\
\hline Mean square & 141,564 & $4,813,916$ & 160,795 \\
\hline$F$ value & $4.9^{*}$ & $438.5^{*}$ & $5.6^{*}$ \\
\hline \multicolumn{4}{|l|}{$\mathrm{Ca}$} \\
\hline Mean square & 830,177 & $4,258,602$ & 110,367 \\
\hline$F$ value & $17.1^{*}$ & $44.9^{*}$ & $6.5^{*}$ \\
\hline \multicolumn{4}{|l|}{$\mathrm{Mg}$} \\
\hline Mean square & 74,632 & 487,479 & 19,740 \\
\hline$F$ value & $24.4 *$ & $196.9^{*}$ & $10.4 *$ \\
\hline \multicolumn{4}{|l|}{$\mathrm{Fe}$} \\
\hline Mean square & 67.4 & 1,052 & 76.2 \\
\hline$F$ value & 0.1 & $307.9 *$ & 1 \\
\hline \multicolumn{4}{|l|}{$\mathrm{Mn}$} \\
\hline Mean square & 999.8 & 932.4 & 536.6 \\
\hline$F$ value & 0.4 & 5.9 & 1.4 \\
\hline \multicolumn{4}{|l|}{$\mathrm{Zn}$} \\
\hline Mean square & 37.2 & 304.6 & 18 \\
\hline$F$ value & $6.0^{*}$ & $72.5^{*}$ & $4.2 *$ \\
\hline
\end{tabular}

${ }^{x}$ Asterisks $(*)$ denote significance level of $F$ test values at $P \leq 0.05$.

${ }^{y}$ Soils were sampled from field plots subjected to tilled fallowing, hay cropping, field vegetable cropping, or high-tunnel vegetable cropping organic transition treatments.

${ }^{\mathrm{z}}$ Each transition treatment included compost-amended $(+\mathrm{C})$ or nonamended subplots. as 100 times the proportion of plants that did not germinate or died after germination in each container or field site. At the end of each experiment, the height and leaf area index of tomato seedlings and number of soybean seedlings reaching the V1 and V2 growth stages were determined. The leaf area index was scored using a four-level ordinal rating scale, where $0=$ shoot growth through the second true leaf visible, $1=$ the first compound leaf emerging, 2 = the first compound leaf fully expanded, and $3=$ the layer of compound leaves $\geq 100 \mathrm{~cm}^{2}$. At the end of each experiment, seedlings were cut at the soil line and pooled for measurements of shoot fresh weights for each container or field site.

Data analyses. A combined analysis of variance was calculated using the general linear model (GLM) procedure of SAS software (PROC GLM, SAS version 8.2; SAS Institute, Carry, NC). Soil chemistry analysis and field bioassays data were analyzed as a split-plot design. The primary treatments were tilled fallowing, single planting of mixed-species perennial hay, low-intensity open field vegetables, and intensive vegetable production under high tunnels, and the secondary treatments were related to fertility management. All factors were fixed in this analysis. Least square means comparisons were used to determine significant differences between the four primary treatments means for compostand noncompost-amended treatments for each parameter measured at $P \leq 0.05$.

Analysis of variance was conducted on stand and vigor data from greenhouse and growth chamber bioassays evaluations using a randomized complete block design in a factorial arrangement, with inoculum and eight different soil transition treatments as the main effects using the GLM procedure of SAS (PROC GLM, SAS version 8.2; SAS Institute). The least significant difference test at $P \leq 0.05$ was calculated to compare differences among the means for pairs of interactions.

\section{RESULTS}

Soil chemistry. Transition cropping treatment had a significant effect on soil chemistry $(P<0.05)$, except Fe and Mn status, as represented by results from the fall sampling of 2005 (Table 1). In the absence of compost addition, several small changes in soil chemistry were observed. First, soils taken from the high-tunnel vegetable cropping treatment had higher values for $\mathrm{pH}$ than the other treatments $(P=0.0002)$. In fact, the average difference was approximately $0.5 \mathrm{pH}$ units. Likewise, extractable $\mathrm{Ca}$ and $\mathrm{Mg}$ were approximately 1.5 times higher than in the other treatments. Also, soils taken from the mixed-species hay treatment had a higher percentage of $\mathrm{C}(P=0.0006)$ than the other treatments. However, multiple pairwise comparisons indicated that, for each level of compost application considered, the differences between transition treatments were rarely significant in the plots not amended with composts. (Table 2). For example, although the mean $(n=4)$ percent $C$ ranged from 0.9 to 1.4 in the unamended soils, the observed differences were not significant $(P>0.1)$.

In general, the compost amendments applied annually during the transition period had a profound affect on all measured variables except Fe and Mn (Table 2). Differences were observed frequently in pairwise comparisons of transition treatments receiving the compost amendments $(P<0.05)$. Values for $\mathrm{pH}$, percent $\mathrm{N}$, and percent $\mathrm{C}$ were higher in all compost-amended transition treatments than the nonamended transition treatments ( $P=0.035,0.0002$, and 0.0002 , respectively). The soils from the compost-amended high-tunnel-covered plots were found to contain the highest concentrations of the assayed elements, presumably because the compost did not decompose as rapidly as in the open-field plots. Indeed, the bulk density of the compostamended high-tunnel plot was noticeably lighter than the corresponding open-field plots by the year of organic certification.

An interaction between compost amendment and transition treatment was observed whereby some variations in soil chemistry 
became apparent only where compost had been applied. Compost amendment in intensive vegetable production under high tunnels significantly increased values for $\mathrm{pH}(P=0.011), \mathrm{P}(P=0.005)$, $\mathrm{K}(P=0.019)$, and $\mathrm{Mg}(P=0.003)$ compared with the other three compost-amended treatments. There were no significant differences in values for percent $\mathrm{N}$, percent $\mathrm{C}, \mathrm{Ca}$, and $\mathrm{Zn}$ among compost-amended mixed-species hay treatment and high-tunnel vegetable cropping treatment. On the other hand, both treatments resulted in higher values for $\mathrm{N}, \mathrm{C}, \mathrm{Ca}$, and $\mathrm{Zn}$ than compostamended tilled fallowing and field vegetable cropping treatments. The color and bulk density of the soils sampled also were affected by the compost amendment, resulting in darker and less dense soil relative to the nonamended transition treatments (data not shown).

Variation in soil nutrient composition of each treatment was not significantly different $(P>0.20)$ between the two sampling times, and analyses of soil chemistry data from the previous spring sampling gave the same result (data not shown).

Greenhouse and growth chamber bioassays: soybean. Across three separate experiments, the lowest levels of dampingoff were observed in the mixed-hay treatment. In experiment 1 , a greenhouse experiment in which no additional pathogen inoculum was added, damping-off disease levels were low in all treatments, ranging from 1.4 to $12.5 \%$, with no significant differences among any factors or treatments $(P=0.19)$ (Fig. 1). However, the observed levels of damping-off were lowest in soils previously cropped to hay $(\mathrm{H})(1.4 \%)$ or hay plus compost $(\mathrm{H}+\mathrm{C})$ plots $(4.2 \%)$. In experiment 2 , a growth chamber assay with additional pathogen inoculum added, transition treatment significantly affected damping-off disease, with the mixed-hay treatments resulting in significantly lower total damping-off than any other transition treatment $(P=0.0001)$. Average damping-off of 39 and $47 \%$ were observed for the $\mathrm{H}$ and $\mathrm{H}+\mathrm{C}$ treatments, which was markedly lower than the 65 to $92 \%$ levels observed in the other treatments. Overall, compost amendment tended to increase damping-off, but only the high-tunnel vegetable treatment without compost had significantly lower damping-off than the same treatment with compost $(P<0.05)$. In experiment 3 , a growth chamber assay in which pathogen inoculum was added and damping-off was very high overall, neither transition treatment nor compost amendment factors significantly affected damping-off. Nonetheless, the $\mathrm{H}$ and $\mathrm{H}+\mathrm{C}$ treatments had the lowest observed levels of damping-off (i.e., 96 and 83\%, respectively).

Although no consistent disease-suppressive effects were observed due to compost addition, the compost amendment typically increased vigor of young soybean plants in all transition treatments except field vegetable cropping treatment (Table 3). Compost amendment in the mixed-species hay soils provided for the greatest fresh weight and the greatest number of plants to the V1 stage with or without additional pathogen inoculum added. In experiment 1 , with no pathogen inoculum added, transition treatments did not significantly affect fresh weight or the number of plants at the V1 stage ( $P=0.29$ and 0.13 , respectively) (Table 3 ). In contrast, compost amendment increased fresh weight and also the number of plants to the V1 stage across transition treatments $(P=0.044$ and 0.023$)$. In experiment 2 , with additional pathogen inoculum added, transition treatments significantly affected fresh weight and the number of plants to the V1 stage $(P<0.0001$ for both). In addition, compost amendment significantly increased fresh weight and the number of plants to the V1 stage $(P<0.001$ for both). In experiment 3 , with additional pathogen inoculum added, transition treatments did not significantly affect fresh weight or the number of plants at the V1 stage ( $P>0.3$ for both). Nonetheless, compost amendment significantly increased fresh

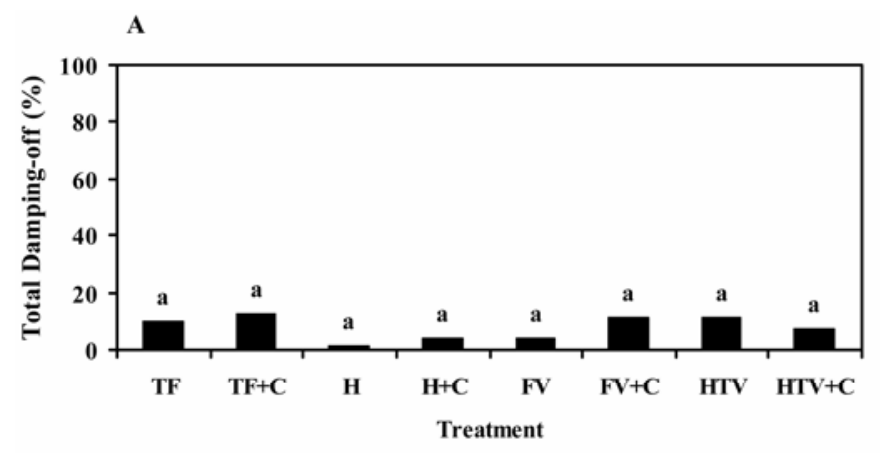

B

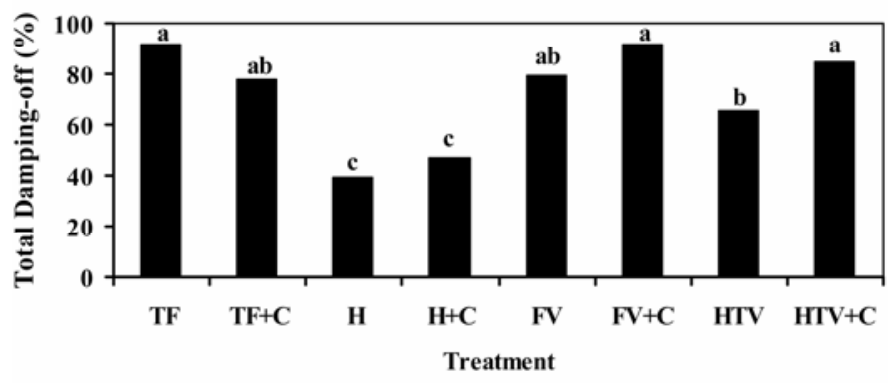

C



Fig. 1. Damping-off of edamame soybean grown in soils of differing field management in $\mathbf{A}$, experiment $1, \mathbf{B}$, experiment 2 , and $\mathbf{C}$, experiment 3 .

TABLE 2. Soil pH, N, C, and extractable nutrient status, fall 2005

\begin{tabular}{|c|c|c|c|c|c|c|c|c|c|c|}
\hline \multirow[b]{2}{*}{ Treatment ${ }^{z}$} & \multirow[b]{2}{*}{$\mathrm{pH}$} & \multicolumn{2}{|c|}{ Percent } & \multicolumn{7}{|c|}{ Quantity of nutrients $(\mu \mathrm{g} / \mathrm{g})$} \\
\hline & & $\mathrm{N}$ & $\mathrm{C}$ & $\mathrm{P}$ & $\mathrm{K}$ & $\mathrm{Ca}$ & $\mathrm{Mg}$ & $\mathrm{Fe}$ & $\mathrm{Mn}$ & $\mathrm{Zn}$ \\
\hline $\mathrm{TF}$ & $6.3 \mathrm{e}$ & $0.1 \mathrm{c}$ & $0.9 \mathrm{c}$ & $40 \mathrm{c}$ & $108 \mathrm{c}$ & $947 \mathrm{~d}$ & $221 \mathrm{e}$ & $158 \mathrm{a}$ & $152 \mathrm{a}$ & $5.4 \mathrm{~cd}$ \\
\hline $\mathrm{TF}+\mathrm{C}$ & $6.8 \mathrm{~cd}$ & $0.2 \mathrm{~b}$ & $2.3 \mathrm{~b}$ & $118 \mathrm{~b}$ & $638 \mathrm{~b}$ & $1,493 \mathrm{c}$ & $370 \mathrm{~cd}$ & $172 \mathrm{a}$ & $155 \mathrm{a}$ & $8.0 \mathrm{bc}$ \\
\hline $\mathrm{H}+\mathrm{C}$ & $6.7 \mathrm{bc}$ & $0.4 \mathrm{a}$ & $4.2 \mathrm{a}$ & $143 \mathrm{~b}$ & $859 \mathrm{~b}$ & $2,093 \mathrm{~b}$ & $521 \mathrm{~b}$ & $175 \mathrm{a}$ & 149 a & $15.1 \mathrm{a}$ \\
\hline $\mathrm{FV}$ & $6.8 \mathrm{~cd}$ & $0.1 \mathrm{c}$ & $0.9 \mathrm{c}$ & $37 \mathrm{c}$ & $101 \mathrm{c}$ & $1,119 \mathrm{~d}$ & $250 \mathrm{e}$ & $153 \mathrm{a}$ & $172 \mathrm{a}$ & $4.3 \mathrm{~d}$ \\
\hline $\mathrm{FV}+\mathrm{C}$ & $7.1 \mathrm{~b}$ & $0.2 \mathrm{~b}$ & $2.6 \mathrm{~b}$ & $140 \mathrm{~b}$ & $741 \mathrm{~b}$ & $1,633 \mathrm{c}$ & $432 \mathrm{c}$ & $168 \mathrm{a}$ & 169 a & $9.2 \mathrm{~b}$ \\
\hline
\end{tabular}

y Values are the means of four replications; means followed by the same letter are not significantly different at $P \leq 0.05$.

${ }^{\mathrm{z}}$ Soils were sampled from field plots subjected to tilled fallowing (TF), hay cropping (H), field vegetable cropping (FV), or high-tunnel vegetable cropping (HTV) organic transition treatments. Each transition treatment included compost-amended $(+C)$ or nonamended subplots. 
weight $(P=0.006)$ and the number of plants to the V1 stage $(P=$ $0.001)$.

Greenhouse and growth chamber bioassays: tomato. Although not as consistent as in the soybean bioassays, the mixedspecies hay treatment did tend to reduce damping-off of tomato in multiple experimental contexts (Fig. 2). In experiment 1, a greenhouse experiment in which no additional pathogen inoculum was added, damping-off disease levels were moderate in all treatments, ranging from 26.7 to $51.3 \%$. Transition treatment affected damping-off $(P=0.040)$, but the hay treatments did not have the lowest levels of damping off. Compost amendment in all treatments resulted in higher damping-off than without compost $(P=$ 0.040 ). In experiment 2 , a growth chamber assay with additional pathogen inoculum added, damping-off disease levels were relatively high in all treatments, ranging from 48.8 to $73.3 \%$. Transition treatment did not significantly affect damping-off disease $(P=0.21)$; however, the two hay treatments had the lowest levels of disease (i.e., 41 and $44 \%$ for $\mathrm{H}$ and $\mathrm{H}+\mathrm{C}$, respectively). In experiment 3 , a growth chamber assay in which pathogen inoculum was added, transition treatment significantly affected damping-off disease overall $(P=0.013)$. In this experiment, the three lowest levels of damping-off levels were observed in the $\mathrm{H}(36 \%)$, high-tunnel vegetable cropping (HTV) (39\%), and $\mathrm{H}+\mathrm{C}(44 \%)$ treatments. Overall, compost amendment did not significantly affect damping-off in any of these three experiments $(P=0.43$, 0.86 , and 0.34 , respectively). Overall, the hay treatment without compost had lower damping-off than the same treatment without compost $(P=0.005)$.

Tomato plants grown in the soils obtained from the hay and high-tunnel treatments tended to be the most vigorous (Table 4). In experiment 1, with no pathogen inoculum added, plant height, fresh weight, and leaf area index of the surviving tomato plants was influenced significantly by transition treatment $(P=0.0001$, 0.034 , and 0.009 , respectively). Compost amendment increased plant height across transition treatments $(P<0.0001)$. Compost amendment in the $\mathrm{H}$ and HTV treatments significantly increased plant height with no additional pathogen inoculum added $(P=$ 0.0001 ). In experiment 2 , with additional pathogen inoculum added, transition treatment marginally affected plant height $(P=$ 0.072 ) but did not significantly affect fresh weight or leaf area index $(P>0.20$ for both). Likewise, compost amendment did not affect plant height, fresh weight, and leaf area index $(P>0.20$ for each). Within transition treatments, however, compost amendment in the high-tunnel vegetable cropping treatment significantly increased plant height and fresh weight with additional pathogen inoculum added $(P<0.0001$ and $P=0.0002$, respectively). In experiment 3 , with additional pathogen inoculum added, transition treatments significantly affected plant height, fresh weight, and leaf area index $(P=0.049,0.004$, and 0.029 , respectively). Also, compost amendment significantly increased plant height, fresh weight, and leaf area index $(P=0.0071,0.0019$, and 0.0039, respectively). Within transition treatments, however, only compost amendment in the HTV cropping treatment significantly increased plant height, fresh weight, and leaf area index with additional pathogen inoculum added $(P<0.0001$ for all paired comparisons).

Field bioassay: soybean. In the year of certification, dampingoff of field-grown soybean was remarkably high ( $>77 \%$ for all treatments) (Fig. 3). In this context, transition treatment still significantly affected damping-off disease $(P=0.001)$, with the mixed-hay transition treatments resulting in significantly lower

A

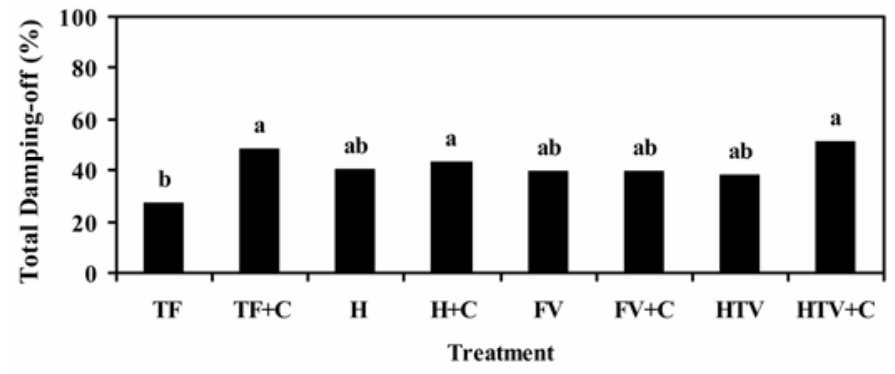

B
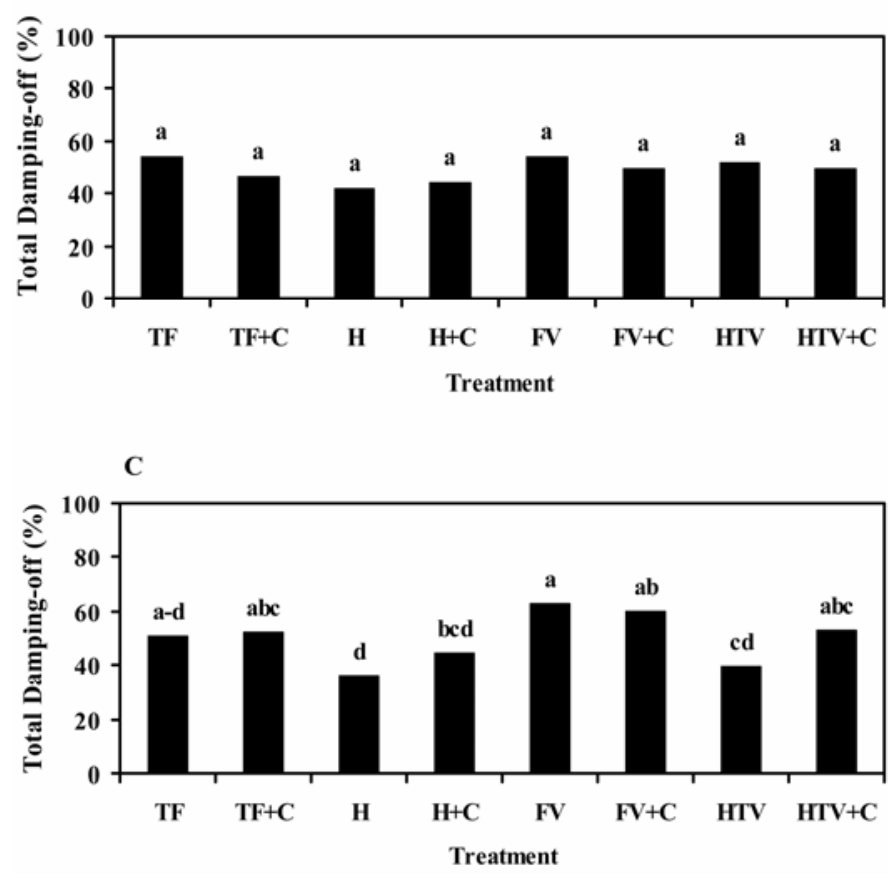

Fig. 2. Damping-off of tomato grown in soils of differing field management in A, experiment $1, \mathbf{B}$, experiment 2 , and $\mathbf{C}$, experiment 3 .

TABLE 3. Vigor of young soybean plants grown in soils differing in field management $\operatorname{practices}^{\mathrm{y}}$

\begin{tabular}{|c|c|c|c|c|c|c|}
\hline \multirow[b]{2}{*}{ Treatment ${ }^{\mathrm{z}}$} & \multicolumn{2}{|c|}{ Experiment 1} & \multicolumn{2}{|c|}{ Experiment 2} & \multicolumn{2}{|c|}{ Experiment 3} \\
\hline & FW/plant (g) & No. of plants & FW/plant (g) & No. of plants & FW/plant (g) & No. of plants \\
\hline $\mathrm{TF}$ & $2.20 \mathrm{bc}$ & $5.0 \mathrm{bc}$ & $0.47 \mathrm{e}$ & $0.2 \mathrm{c}$ & $0.05 \mathrm{~b}$ & $0.0 \mathrm{~b}$ \\
\hline $\mathrm{TF}+\mathrm{C}$ & $2.40 \mathrm{ab}$ & $5.0 \mathrm{bc}$ & $0.76 \mathrm{de}$ & $0.3 \mathrm{c}$ & $0.25 \mathrm{~b}$ & $0.2 \mathrm{~b}$ \\
\hline $\mathrm{H}$ & $2.25 \mathrm{bc}$ & $5.8 \mathrm{a}$ & $2.16 \mathrm{ab}$ & $2.8 \mathrm{a}$ & $0.25 \mathrm{~b}$ & $0.2 \mathrm{~b}$ \\
\hline $\mathrm{H}+\mathrm{C}$ & $2.38 \mathrm{ab}$ & $5.6 \mathrm{ab}$ & $2.42 \mathrm{a}$ & $2.3 \mathrm{a}$ & $1.18 \mathrm{a}$ & $0.8 \mathrm{a}$ \\
\hline $\mathrm{FV}$ & $2.32 \mathrm{~b}$ & $5.5 \mathrm{ab}$ & $1.33 \mathrm{~cd}$ & $0.5 \mathrm{bc}$ & $0.25 \mathrm{~b}$ & $0.2 \mathrm{~b}$ \\
\hline $\mathrm{FV}+\mathrm{C}$ & $2.22 \mathrm{bc}$ & $4.4 \mathrm{c}$ & $0.67 \mathrm{de}$ & $0.2 \mathrm{c}$ & $0.00 \mathrm{~b}$ & $0.0 \mathrm{~b}$ \\
\hline HTV & $2.05 \mathrm{c}$ & $5.2 \mathrm{ab}$ & $1.51 \mathrm{bc}$ & $1.1 \mathrm{~b}$ & $0.00 \mathrm{~b}$ & $0.0 \mathrm{~b}$ \\
\hline $\mathrm{HTV}+\mathrm{C}$ & $2.55 \mathrm{a}$ & $5.3 \mathrm{ab}$ & $1.11 \mathrm{cde}$ & $0.4 \mathrm{bc}$ & $0.17 \mathrm{~b}$ & $0.1 \mathrm{~b}$ \\
\hline
\end{tabular}

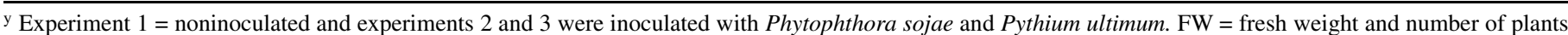
was counted at the VI growth stage. Values are the means of three replications; means followed by the same letter are not significantly different at $P \leq 0.05$.

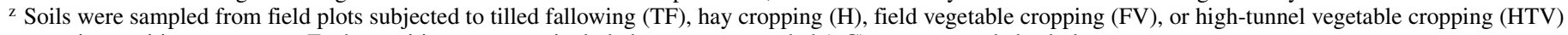
organic transition treatments. Each transition treatment included compost-amended $(+\mathrm{C})$ or nonamended subplots. 
total damping-off rate of soybean plants than any other transition treatments ( 77 to 89 versus 91 to $98 \%$ ). Overall, compost amendment did not significantly affect damping-off. However, the mixedhay transition treatment with compost did have lower damping-off than the same treatment without compost.

Transition treatment also significantly affected vigor of the soybean plants surviving in the field plots (Table 5), with the mixedhay transition treatment resulting in significantly higher fresh weight and the number of plants to the V1 and V2 stages than any other transition treatment $(P=0.0014,0.0046$, and 0.0075, respectively) (Table 6). Compost amendment did not significantly affect fresh weight or the number of plants to the V1 and V2 stages. Nevertheless, plants grown in the $\mathrm{H}+\mathrm{C}$ transition plots had higher fresh weight and increased numbers of plants to the V1 and $\mathrm{V} 2$ stages than the $\mathrm{H}$ transition plots.

Field bioassay: tomato. In the year of certification, transition treatment significantly affected damping-off disease $(P=0.037)$ (Fig. 4). As in the soybean bioassays, the plots previously experiencing the mixed-hay transition treatments had lower levels of damping-off (53 and $61 \%$ for $\mathrm{H}$ and $\mathrm{H}+\mathrm{C}$, respectively) than the other treatments (65 to $78 \%$ ). Overall, compost amendment did not significantly affect damping-off.

However, in contrast to the results with soybean, there were no significant differences among transition treatments and compost amendment to transition treatments in the plant height, fresh weight, and leaf area index of tomato plants under field conditions (Tables 7 and 8). Nonetheless, trends to increased vigor were observed in the compost-amended plots compared with those not receiving compost.

\section{DISCUSSION}

Beyond short-term economic returns, farmers wishing to transition to certified organic production are looking for transition strategies that will provide a productive environment post certification. This study highlights how transition strategy can alter the relative degree of soilborne disease suppressiveness to different oomycete pathogens. Specifically, we noted that the hay treatments reducing damping-off in seven of eight experimental contexts relative to the corresponding treatments whether or not compost was applied. For both crops, this pattern was significant in the field and in one of the three growth chamber contexts (i.e., experiment 2 for soybean and experiment 3 for tomato). In those instances, the magnitude of the observed reductions in mean percent damping-off ranged from 2 to $53 \%$ for soybean and 3 to $27 \%$ for tomato. Such a result indicates that the hay transition can provide organic farmers with some quantifiable insurance against subsequent outbreaks of soilborne diseases such as damping-off, at least during the initial year of certification. However, the magnitude of the response alone during the initial year of certification may not be enough to justify the potential opportunity costs of applying the hay treatment during the transition period. Thus, it will be interesting to determine the period over which such induced suppressiveness persists in the years following certification.

Studies of mixtures of grasses and legumes as cover crops have demonstrated a benefit to agricultural systems, through the improvement of soil characteristics such as aggregate structure, $\mathrm{N}$ availability and organic matter content in soil (10). The mixedhay treatment used here consisted of a combination of eight hay species. Although this mixture likely provides an interesting mix of carbon and nitrogen sources for soil- and root-inhibiting microbes, it is unclear whether the composition or the relative abundance of fixed nutrients stimulated the elevated levels of disease suppressiveness noted in this study. Nonetheless, multiple studies indicate that increasing plant diversity can reduce soilborne disease pressure. For instance, a decrease in replant disorder in strawberry was observed in plants grown in multiplespecies rotation systems (35). Cover crops also have been shown to increase the populations of beneficial organisms in soil and reduce disease incidence (34). In native grasslands, differences in suppressiveness to pathogen growth also have been observed when compared with arable land under rotation or monoculture (39), indicating the importance of soil organic matter in generating and maintaining general suppressiveness to soilborne root diseases. Interestingly, these grasslands harbor higher diversity of Pseudomonas and Burkholderia spp. antagonistic to $R$. solani compared with the arable land $(13,31)$. These two genera are known to harbor strains with significant capacities to suppress soilborne pathogens (23), some of which have been developed as biological control agents (12). Recently, native populations of Pseudomonas spp. have been positively correlated to crop health (29), and it is possible that native populations of these bacteria

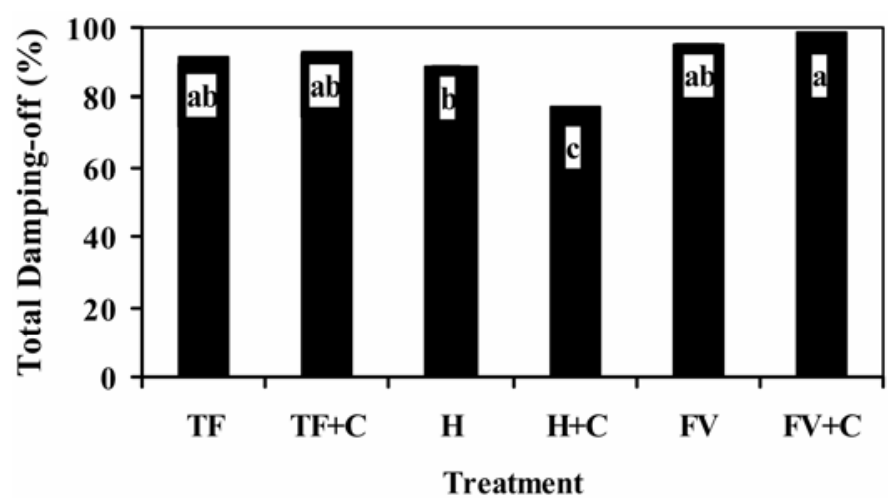

Fig. 3. Damping-off of soybean plants grown under field conditions with different management practices. Treatments: $\mathrm{TF}=$ tilled fallowing, $\mathrm{C}=$ compost, $\mathrm{H}=$ mixed-species perennial hay, and $\mathrm{FV}=$ low-intensity open field vegetables.

TABLE 4. Vigor of young tomato plants grown in soils differing in field management practices ${ }^{\mathrm{y}}$

\begin{tabular}{|c|c|c|c|c|c|c|c|c|c|}
\hline \multirow[b]{2}{*}{ Treatment $^{z}$} & \multicolumn{3}{|c|}{ Experiment 1} & \multicolumn{3}{|c|}{ Experiment 2} & \multicolumn{3}{|c|}{ Experiment 3} \\
\hline & Ht/plant (cm) & FW/plant (g) & Area & Ht/plant (cm) & FW/plant (g) & Area & Ht/plant (cm) & FW/plant (g) & Area \\
\hline $\mathrm{TF}$ & $5.9 \mathrm{de}$ & $0.52 \mathrm{abc}$ & $1.6 \mathrm{ab}$ & $2.4 \mathrm{c}$ & $0.15 \mathrm{~cd}$ & $2.0 \mathrm{bc}$ & $1.7 \mathrm{c}$ & $0.42 \mathrm{c}$ & $2.0 \mathrm{c}$ \\
\hline $\mathrm{TF}+\mathrm{C}$ & $6.6 \mathrm{~cd}$ & $0.51 \mathrm{abc}$ & $1.8 \mathrm{a}$ & $4.1 \mathrm{~b}$ & $0.23 \mathrm{bcd}$ & $2.5 \mathrm{a}$ & $3.1 \mathrm{~b}$ & $1.46 \mathrm{~b}$ & $3.0 \mathrm{~b}$ \\
\hline $\mathrm{H}$ & $6.9 \mathrm{c}$ & $0.47 \mathrm{bc}$ & $1.7 \mathrm{ab}$ & $1.8 \mathrm{c}$ & $0.08 \mathrm{~d}$ & $1.6 \mathrm{c}$ & $2.4 \mathrm{bc}$ & $0.75 \mathrm{bc}$ & $2.4 \mathrm{bc}$ \\
\hline $\mathrm{H}+\mathrm{C}$ & $8.8 \mathrm{~b}$ & $0.72 \mathrm{a}$ & $1.7 \mathrm{ab}$ & $4.2 \mathrm{~b}$ & $0.34 \mathrm{ab}$ & $2.5 \mathrm{a}$ & $3.0 \mathrm{~b}$ & $1.28 \mathrm{~b}$ & $3.3 \mathrm{~b}$ \\
\hline FV & $5.4 \mathrm{e}$ & $0.39 \mathrm{c}$ & $1.4 \mathrm{~b}$ & $2.4 \mathrm{c}$ & $0.09 \mathrm{~d}$ & $1.8 \mathrm{c}$ & $2.0 \mathrm{bc}$ & $0.45 \mathrm{c}$ & $2.1 \mathrm{c}$ \\
\hline $\mathrm{FV}+\mathrm{C}$ & $7.5 \mathrm{c}$ & $0.54 \mathrm{abc}$ & $1.8 \mathrm{a}$ & $4.4 \mathrm{ab}$ & $0.28 \mathrm{abc}$ & $2.4 \mathrm{ab}$ & $2.6 \mathrm{bc}$ & $0.80 \mathrm{bc}$ & $2.7 \mathrm{bc}$ \\
\hline HTV & $7.4 \mathrm{c}$ & $0.63 \mathrm{ab}$ & $1.9 \mathrm{a}$ & $2.6 \mathrm{c}$ & $0.26 \mathrm{abc}$ & $1.9 \mathrm{c}$ & $2.9 \mathrm{~b}$ & $1.01 \mathrm{bc}$ & $3.1 \mathrm{~b}$ \\
\hline $\mathrm{HTV}+\mathrm{C}$ & $9.9 \mathrm{a}$ & $0.65 \mathrm{ab}$ & $1.8 \mathrm{a}$ & $5.2 \mathrm{a}$ & $0.43 \mathrm{a}$ & $2.7 \mathrm{a}$ & $4.9 \mathrm{a}$ & $3.01 \mathrm{a}$ & $4.5 \mathrm{a}$ \\
\hline
\end{tabular}

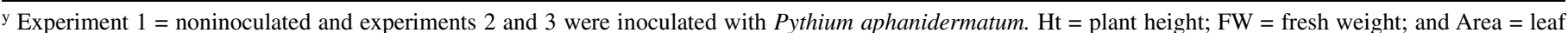
area index, which was assessed based on a four-level rating system, where $0=$ shoot growth through the second true leaf visible, $1=$ the first compound leaf

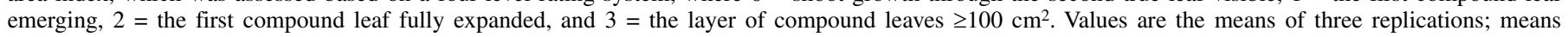
followed by the same letter are not significantly different at $P \leq 0.05$.

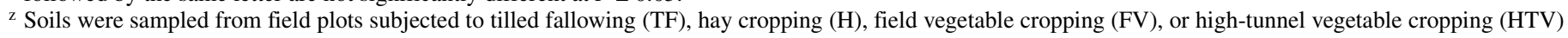
organic transition treatments. Each transition treatment included compost-amended $(+\mathrm{C})$ or nonamended subplots. 
TABLE 5. Analysis of variance for vigor of young soybean plants grown under field conditions

\begin{tabular}{|c|c|c|c|c|c|c|c|c|c|}
\hline \multirow[b]{2}{*}{ Source } & \multirow[b]{2}{*}{ df } & \multicolumn{2}{|c|}{ Fresh weight/plant (g) } & \multicolumn{2}{|c|}{ No. of stage V1 plants } & \multicolumn{2}{|c|}{ No. of stage V2 plants } & \multicolumn{2}{|c|}{ Total damping-off $(\%)$} \\
\hline & & Mean square & $F$ value $^{\mathrm{x}}$ & Mean square & $F$ value $^{\mathrm{x}}$ & Mean square & $F$ value $^{\mathrm{x}}$ & Mean square & $F$ value $^{\mathrm{x}}$ \\
\hline Treatment ${ }^{\mathrm{y}}$ & 2 & 209.6 & $23.6^{*}$ & 10.3 & $12.4^{*}$ & 6.8 & $15.1^{*}$ & 386.1 & $27.6^{*}$ \\
\hline Compost $^{\mathrm{z}}$ & 1 & 26.3 & 4.0 & 0.7 & 0.5 & 0.1 & 0.1 & 32.9 & 2.1 \\
\hline Treatment $\times$ compost & 2 & 57.4 & 2.9 & 4.2 & 1.8 & 1.9 & 2.7 & 133.1 & 1.5 \\
\hline
\end{tabular}

x Asterisks (*) denote significance level of $F$ test values at $P \leq 0.05$.

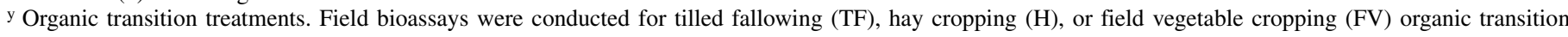
treatments.

${ }^{\mathrm{z}}$ Compost amendment. Each transition treatment included compost-amended $(+\mathrm{C})$ or nonamended subplots.

TABLE 6. Vigor of young soybean plants grown under field conditions with different management practices ${ }^{\mathrm{y}}$

\begin{tabular}{lccc}
\hline Treatment $^{\mathrm{z}}$ & $\begin{array}{c}\text { Fresh weight/ } \\
\text { plant }(\mathrm{g})\end{array}$ & $\begin{array}{c}\text { No. of } \\
\text { stage V1 plants }\end{array}$ & $\begin{array}{c}\text { No. of } \\
\text { stage V2 plants }\end{array}$ \\
\hline $\mathrm{TF}$ & $4.61 \mathrm{bc}$ & $1.5 \mathrm{~b}$ & $0.6 \mathrm{bc}$ \\
$\mathrm{TF}+\mathrm{C}$ & $3.70 \mathrm{bc}$ & $1.0 \mathrm{~b}$ & $0.1 \mathrm{bc}$ \\
$\mathrm{H}$ & $6.87 \mathrm{~b}$ & $1.6 \mathrm{~b}$ & $1.3 \mathrm{~b}$ \\
$\mathrm{H}+\mathrm{C}$ & $15.15 \mathrm{a}$ & $3.6 \mathrm{a}$ & $2.5 \mathrm{a}$ \\
$\mathrm{FV}$ & $1.54 \mathrm{bc}$ & $0.6 \mathrm{~b}$ & $0.4 \mathrm{bc}$ \\
$\mathrm{FV}+\mathrm{C}$ & $0.46 \mathrm{c}$ & $0.1 \mathrm{~b}$ & $0.0 \mathrm{c}$ \\
\hline
\end{tabular}

$\mathrm{y}$ Values are the means of four replications; means followed by the same letter are not significantly different at $P \leq 0.05$.

${ }^{\mathrm{z}}$ Field bioassays were conducted for tilled fallowing (TF), hay cropping $(\mathrm{H})$, or field vegetable cropping $(\mathrm{FV})$ organic transition treatments. Each transition treatment included compost-amended $(+C)$ or nonamended subplots.

contribute significantly to soilborne disease suppression in this system as well as more generally. Indeed, an intensive study of the bacterial communities present in our experimental system has indicated that multiple Burkholderiales species are positively associated with disease suppressiveness (2). Currently, we are attempting to characterize the diversity, population dynamics, and disease-suppressing activities of those populations (M.-S. Benitez and B. B. McSpadden Gardener, unpublished results).

One goal of transition may be to build soil fertility prior to certification. In this study, substantial increases in soil fertility were realized following annual compost applications applied during the transition period (Table 1). That increase in fertility likely contributed to the often substantial yield differences between amended and unamended plots, regardless of transition treatment (M. Kleinhenz and B. McSpadden Gardener, unpublished results). Although compost amendments can significantly reduce seedling diseases caused by oomycetes, the composition, rate, and timing can influence the degree to which general suppression is supported (14). In this research, 3 years of compost amendment did not consistently reduce damping-off across all transition treatments. In addition, compost in conjunction with the mixed-species hay transition treatment only occasionally provided more consistent disease suppression than hay treatment alone. Compost effects on suppression have been related to amendment characteristics and soil type (14). For instance, Scheuerell et al. (32) analyzed the suppressiveness of damping-off of cucumber of 36 compost sources; $60 \%$ of the composts significantly suppressed P. irregulare and P. ultimum, but only $17 \%$ suppressed $R$. solani. Similarly, Termorshuizen et al. (36) assayed the suppressiveness of 18 different composts in seven pathosystems and significant disease suppression was observed in only $54 \%$ of the bioassays performed. Other research has shown that Pythium spp. are readily suppressed by composts when applied to both field and greenhouse media (14). Our data similarly support the view that disease suppressiveness is a secondary and more variable benefit conferred by compost applications, at least in a generally healthy agricultural soil.

Although consistent suppression of soilborne disease by addition of organic nutrients may be difficult to achieve, the added fertility still can confer value to the crop. Soil physical properties

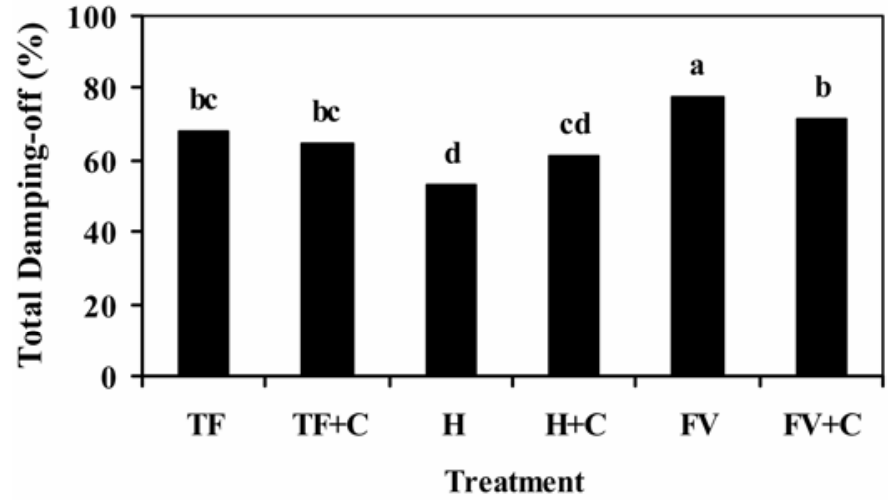

Fig. 4. Damping-off of tomato plants grown under field conditions with different management practices. Treatments: $\mathrm{TF}=$ tilled fallowing, $\mathrm{C}=$ compost, $\mathrm{H}=$ mixed-species perennial hay, and $\mathrm{FV}=$ low-intensity open field vegetables.

are considered a critical component of soil quality (17), and research has shown that addition of organic waste materials can greatly improve a soil's physical properties and fertility levels (9). Regular additions of organic materials such as animal manures and crop residues maintain the tilth, fertility, and productivity of agricultural soils (15). Here, we saw significant increases in crop vigor (Tables 2, 3, 4, and 5) in response to compost amendments applied during the transition period, and these increases were correlated with increased fertility (Table 1) of those soils. Animal manure has long been used as a source of plant nutrients and organic matter to improve fertility conditions of agricultural lands (5). Schlegel (33) showed that soil P, K, and organic matter increased linearly with increased rates of composted manure, and concluded that amending soil with composted manure is effective for maintaining or increasing soil nutrient levels, especially $\mathrm{P}$, without excessive accumulation of $\mathrm{NO}_{3}-\mathrm{N}$. Likewise, Cuevas et al. (4) explained that available $\mathrm{P}$ and $\mathrm{K}$ and concentration of $\mathrm{NO}_{3^{-}}$ $\mathrm{N}$ increased significantly after a composted municipal solid waste application. Although it seems likely that the amount of organic matter that might feed microbial populations that contribute to general soil suppressiveness is greater in the compost-amended soils for newly certified organic land, it was the fertility component that supplied the greatest benefit to early season growth of the crop. Other treatments that can increase the consistency of suppression include manipulation of the soil environment to increase the population of specific indigenous antagonists and soil amendment with organic matter fortified with antagonists (16).

Overall, this study indicates that different transition strategies can lead to significant changes in soilborne disease suppression in newly certified organic land. The microbiological basis for the damping-off suppression associated here with the mixed-hay strategy is currently under study. To date, variations in bacterial population structure have been analyzed using multivariate analyses (2). In that work, several distinct terminal restriction fragments (TRFs) were associated with the mixed-hay transition treatments and the damping-off suppression described in this study. Subsequent work has led to the identification and directed isola- 
TABLE 7. Analysis of variance for vigor of young tomato plants grown under field conditions

\begin{tabular}{|c|c|c|c|c|c|c|c|c|c|}
\hline \multirow[b]{2}{*}{ Source } & \multirow[b]{2}{*}{ df } & \multicolumn{2}{|c|}{ Fresh weight/plant (g) } & \multicolumn{2}{|c|}{ Plant height/plant $(\mathrm{cm})$} & \multicolumn{2}{|c|}{ Leaf area index ${ }^{w}$} & \multicolumn{2}{|c|}{ Total damping-off (\%) } \\
\hline & & Mean square & $F$ value & Mean square & $F$ value & Mean square & $F$ value & Mean square & $F$ value $^{\mathrm{x}}$ \\
\hline Treatment $^{\mathrm{y}}$ & 2 & 0.9 & 1.0 & 1.5 & 1.4 & 0.5 & 1.5 & 610.0 & $6.0 *$ \\
\hline Compost ${ }^{\mathrm{z}}$ & 1 & 5.4 & 5.9 & 3.6 & 1.9 & 0.9 & 1.3 & 2.9 & 0.1 \\
\hline Treatment $\times$ compost & 2 & 0.2 & 0.1 & 0.6 & 0.2 & 0.1 & 0.1 & 111.9 & 1.5 \\
\hline
\end{tabular}

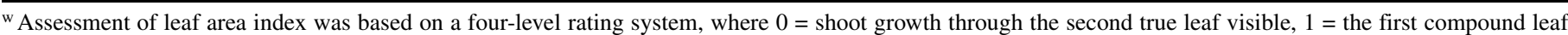
emerging, 2 = the first compound leaf fully expanded, and $3=$ the layer of compound leaves $\geq 100 \mathrm{~cm}^{2}$.

x Asterisk (*) denotes significance level of $F$ test values at $P \leq 0.05$.


treatments.

${ }^{\mathrm{z}}$ Compost amendment. Each transition treatment included compost-amended $(+\mathrm{C})$ or nonamended subplots.

TABLE 8. Vigor of young tomato plants grown under field conditions with different management practices ${ }^{\mathrm{x}}$

\begin{tabular}{lccc}
\hline Treatment ${ }^{\mathrm{y}}$ & $\begin{array}{c}\text { Plant height/ } \\
\text { plant }(\mathrm{cm})\end{array}$ & $\begin{array}{c}\text { Fresh weight/ } \\
\text { plant }(\mathrm{g})\end{array}$ & Leaf area index \\
\hline TF & $5.1 \mathrm{a}$ & $1.89 \mathrm{ab}$ & $3.2 \mathrm{a}$ \\
$\mathrm{TF}+\mathrm{C}$ & $5.7 \mathrm{a}$ & $2.51 \mathrm{a}$ & $3.5 \mathrm{a}$ \\
$\mathrm{H}$ & $4.2 \mathrm{a}$ & $1.01 \mathrm{~b}$ & $3.1 \mathrm{a}$ \\
$\mathrm{H}+\mathrm{C}$ & $5.6 \mathrm{a}$ & $2.23 \mathrm{ab}$ & $3.6 \mathrm{a}$ \\
$\mathrm{FV}$ & $4.3 \mathrm{a}$ & $1.15 \mathrm{~b}$ & $2.8 \mathrm{a}$ \\
FV+C & $4.7 \mathrm{a}$ & $2.15 \mathrm{ab}$ & $3.0 \mathrm{a}$ \\
\hline
\end{tabular}

${ }^{x}$ Values are the means of four replications; means followed by the same letter are not significantly different at $P \leq 0.05$.

y Field bioassays were conducted for tilled fallowing (TF), hay cropping $(\mathrm{H})$, or field vegetable cropping $(\mathrm{FV})$ organic transition treatments. Each transition treatment included compost-amended $(+C)$ or nonamended sub-plots.

${ }^{\mathrm{z}}$ Assessment of leaf area index was based on a four-level rating system, where $0=$ shoot growth through the second true leaf visible, $1=$ the first compound leaf emerging, 2 = the first compound leaf fully expanded, and $3=$ the layer of compound leaves $\geq 100 \mathrm{~cm}^{2}$.

tion of bacteria corresponding to those TRFs, and they have been shown to express pathogen-suppressive activities (M.-S. Benitez and B. B. McSpadden Gardener, unpublished data). Further analyses will be aimed at identifying any eukaryotic microbes associated with the mixed-hay-associated suppression. Studies such as these that are based on community profiling methods (3) are expected to lay the foundation for further advancement in our understanding and management of the microbiological basis for induced suppression to soilborne diseases.

\section{ACKNOWLEDGMENTS}

This work was supported by funds provided by the United States Department of Agriculture CSREES Integrated Research, Extension, and Education, Organic Transitions Grants Program (Award No. GRT961507). We thank S. Walker, M. Sutter, and their field crew for field site management; and G. Agar, C. Nava Diaz, A. Camp, and D. Chavez for suggestions and assistance with sample collection and stand counts.

\section{LITERATURE CITED}

1. AOAC Official Methods of Analysis. 1990. Method 990.03. Protein (crude) in Animal Feed Combustion Method (Dumas method). 15th ed. Reference: JAOAC 51:766(1968).

2. Benitez, M. S., Baysal, F., Rotenberg, D., Kleinhenz, M. D., Cardina, J., Stinner, D., Miller, S. A., and McSpadden Gardener, B. B. 2007. Multiple statistical approaches of community fingerprint data reveal bacterial populations associated with general disease suppression arising from the application of different organic field management strategies. Soil Biol. Biochem. 39:2289-2301

3. Borneman, J., Becker, J. O., Bent, E., Lanoil, B., Gardener, B. M., Olatinwo, R., Presley, L., Scupham, A. J., Valinsky, L., and Yin, B. 2007. Identifying microorganisms involved in specific in situ functions: experimental design considerations for rRNA gene-based population studies and sequence-selective PCR assays. Pages 748-757 in: Manual for Environmental Microbiology, 3rd ed. C. Hurst, ed. ASM Press, Washington, DC.

4. Cuevas, G., Blázquez, R., Martinez, F., and Walter, I. 2000. Composted
MSW effects on soil properties and native vegetation in a degraded semiarid shrubland. Compost Sci. Util. 8:303-309.

5. Dao, T. H., and Cavigelli, M. A. 2003. Mineralizable carbon, nitrogen, and water-extractable phosphorus release from stockpiled and composted manure and manure-amended soils. Agron. J. 95:405-413.

6. Delate, K., and Cambardella, C. 2001. Long-term agroecological research: comparison of organic and conventional grain systems in Iowa. Leopold Center for Sustainable Agriculture Annual Report. LCSA, Iowa State University, Ames.

7. Dick, W. A., and McCoy, E. L. 1993. Enhancing soil fertility by addition of compost. Pages 662-644 in: Science and Engineering of Composting: Design, Environmental, Microbial and Utilization Aspects. H. A. J. Hoitink and H. M. Keener, eds. Renaissance Publications, Worthington, $\mathrm{OH}$.

8. Doran, J. S., Fraser, D. G., Culik, M. W., and Liebhardt, W. C. 1987. Influence of alternative and conventional agriculture management on soil microbial processes and nitrogen availability. Am. J. Alt. Agric. 2 (3):99106.

9. Epstein, E. 1975. Effect of sewage sludge on some soil physical properties. J. Environ. Qual. 4:139-142.

10. Fageria, N. K., Baligar, V. C., and Bailey, B. A. 2005. Role of cover crops in improving soil and row crop productivity. Commun. Soil Sci. Plant Anal. 36:2733-2757.

11. Feng, Y., Motta, A. C., Reeves, D. W., Burmester, C. H., van Santen, E., and Osborne, J. A. 2003. Soil microbial communities under conventionaltill and no-till continuous cotton systems. Soil Biol. Biochem. 35:16931703.

12. Fravel, D. R. 2005. Commercialization and implementation of biocontrol. Annu. Rev. Phytopathol. 43:337-359.

13. Garbeva, P., van Veen, J. A., and van Elsas, J. D. 2004. Assessment of the diversity, and antagonism towards Rhizoctonia solani AG3, of Pseudomonas species in soil from different agricultural regimes. FEMS Microbiol. Ecol. 47:51-64.

14. Hoitink, H. A. J., and Boehm, M. J. 1999. Biocontrol within the context of soil microbial communities: a substrate-dependent phenomenon. Annu. Rev. Phytopathol. 37:427-446.

15. Hornick, S., and Parr, J. 1987. Restoring the productivity of marginal soils with organic amendments. Am. J. Alt. Agric. 2:64-68.

16. Huang, J. W., and Kuhlman, E. G. 1991. Formulation of a soil amendment to control damping-off of slash pine seedlings. Phytopathology 81:163170.

17. Kutilek, M. 2004. Soil hydraulic properties as related to soil structure. Soil Tillage Res. 79:175-184.

18. Lal, R., and Bruce, J. P. 1999. The potential of world cropland soils to sequester $\mathrm{C}$ and mitigate the greenhouse effect. Environ. Sci. Policy 2:77185.

19. Larkin, R. P. 2003. Characterization of soil microbial communities under different potato cropping systems by microbial population dynamics, substrate utilization, and fatty acid profiles. Soil Biol. Biochem. 35:14511466.

20. Larkin, R. P., and Honeycutt, C. W. 2006. Effects of different 3-year cropping systems on soil microbial communities and Rhizoctonia diseases of potato. Phytopathology 96:0068-0079.

21. Liebhardt, W. C., Andrews, W., Culik, M. N., Harwood, R. R., Janke, R. R., Radke, J. K., and Rieger-Schwartz, S. L. 1989. Crop production during conversion from conventional to low-input methods. Agron. J. $81: 150-159$.

22. MacRae, R. J., Hill, S. B., Mehuys, G. R., and Henning, J. 1993. Specific genomic fingerprints of phytopathogenic Xanthomonas and Pseudomonas pathovars and strains generated with repetitive sequences and PCR. Appl. Environ. Microbiol. 60:2286-2295.

23. McSpadden Gardener, B. 2007. Diversity and ecology of biocontrol Pseudomonas in agricultural systems. Phytopathology 97:221-226.

24. Mehlich 3 soil test extractant. 1984. A modification of Mehlich 2 
extractant. Commun. Soil Sci. Plant Anal. 15(12):1409-1416.

25. Nava Diaz, C. 2005. Role of plant growth-promoting rhizobacteria in integrated disease management and productivity of tomato. Dissertation, Plant Pathology, Ohio State University, Wooster.

26. Paul, E. A., Harris, D., Collins, H. P., Schulthess, U., and Robertson, G. P. 1999. Evolution of $\mathrm{CO}_{2}$ and soil carbon dynamics in biologically managed, row-crop agroecosystems. Appl. Soil Ecol. 11:53-65.

27. Perez-Piqueres, A., Edel-Hermann, W., Alabouvette, C., and Steinberg, C. 2006. Response of soil microbial communities to compost amendments. Soil Biol. Biochem. 38:460-470.

28. Pfiffner, L., and Niggli, U. 1996. Effects of bio-dynamic, organic and conventional farming on ground beetles and other Epigaeic arthropods in winter wheat. Biol. Agric. Hortic. 12:353-364.

29. Rotenberg, D., Joshi, R., Benitez, M. S., Gutierrez Chapin, L., Camp, A., Zumpetta, C., Osborne, A., Dick, W. A., and McSpadden Gardener, B. 2007. Complex effects of farm management on rhizosphere colonization by native populations of phlD-containing Pseudomonas spp. and the relative contribution of those bacteria to crop stand and productivity. Phytopathology 97:756-766.

30. Sahs, W. W., and Lesoing, G. 1985. Crop rotation and manure versus agricultural chemicals in dryland grain production. J. Soil Water Conserv. 40:511-516.

31. Salles, J. F., van Elsas, J. D., and van Veen, J. A. 2006. Effect of agricultural management regime on Burkholderia community structure in soil. Microbiol. Ecol. 52:267-279.

32. Scheuerell, S. J., Sullivan, D. M., and Mahaffee, W. F. 2005. Suppression of seedling damping-off caused by Pythium ultimum, P. irregulare, and Rhizoctonia solani in container media amended with a diverse range of Pacific Northwest compost sources. Phytopathology 95:306-315.

33. Schlegel, A. J. 1992. Effect of composted manure on soil chemical properties and nitrogen use by grain-sorghum. J. Prod. Agric. 5:153-157.

34. Schutter, M. E., and Dick, R. P. 2002. Microbial community profiles and activities among aggregates of winter fallow and cover-cropped soil. Soil Sci. Soc. Am. J. 66:142-153.

35. Seigies, A. T., and Pritts, M. 2006. Cover crop rotations alter soil microbiology and reduce replant disorders in strawberry. HortScience 41:1303-1308.

36. Termorshuizen, A. J., van Rijn, E., van der Gaag, D. J., Alabouvette, C., Chen, Y., Lagerlof, J., Malandrakis, A. A., Paplomatas, E. J., Ramert, B., and Ryckeboer, J. 2006. Suppressiveness of 18 composts against 7 pathosystems: Variability in pathogen response. Soil Biol. Biochem. 38:2461-2477.

37. Tiquia, S. M., Lloyd, J., Herms, D. A., Hoitink, H. A. J., and Michel, F. C. 2002. Effects of mulching and fertilization on soil nutrients, microbial activity and rhizosphere bacterial community structure determined by analysis of TRFLPs of PCR-amplified 16S rRNA genes. Appl. Soil Ecol. 21:31-48.

38. Tuitert, G., Szczech, M. M., and Bollen, G. J. 1998. Suppression of Rhizoctonia solani in potting mixes amended with compost made from organic household waste. Phytopathology 88:764-773.

39. van Elsas, J. D., Garbeva, P., and Salles, J. 2002. Effects of agronomical measures on the microbial diversity of soils as related to the suppression of soil-borne plant pathogens. Biodegradation 13:29-40.

40. Wander, M. M., Traina, S. J., Stinner, B. R., and Peters, S. E. 1994 Organic and conventional management effects on biologically active soil organic matter pools. Soil Sci. Soc. Am. J. 58:1130-1139.

41. Watson, M. E., and Brown, J. R. 1998. pH and lime requirement. Chapter 4, page 13 in: Recommended Chemical Soil Test Procedures for the North Central Region. NCR Publ. No. 221. Missouri Agricultural Experiment Station, Columbia. 